\title{
METODE INTERAKSI PARENTING: UPAYA MENGOPTIMALKAN PENDIDIKAN SISWA SEJAK DINI
}

\author{
H. Moh. Rifai *
}

\begin{abstract}
Parents are obliged to take care of their children's future, especially by rendering sufficient education. Children are believed to bring about happiness every now and then, who generate family's pride up to the almighty judication. Some people are save and some are not in that court, where children will give sigificant contribution in it. That's why the children's well being has become the parents obligation. To bring about children's well being, parents should also render the good treatments during the life cycle of their children. The main duties of parents for their children are giving them the good names, sending them to the good schools where they can learn religion, and marry them to their good spouses. Psychologically, when children are sent to school for the first time, they will feel that they are put apart from parents' care, so that may of them have to go difficult phase of adjustment. The adjustment includes that of education so as to run as naturally as possible. To get the naturality of the education delegation, teachers and educators are obliged to be able to nurture any value to students as naturally as possible. Parenting model of teaching serves the requirements of teaching children just the way the parrents do, so that it is assumptively effective in teaching elementary students by taking consideration on the psychologial aspect of children.
\end{abstract}

Keywords: Parenting Model of teaching, children education optimalization

\begin{abstract}
Abstrak
Orangtua memiliki kewajiban memerhatikan masa depan anak, khususnya pendidikan. Anak adalah perhiasan kehidupan dunia bahkan menjadi penentu kebahagiaan di akhirat. Anak juga sebagai penyambung generasi serta kebanggaan dalam keluarga yang kelak akan menjadi bukti ketika manusia diadili oleh Allah nanti. Ada manusia yang selamat atau ada yang tidak, dalam timbangan keadilan oleh Allah, anak ikut menentukan. Anak adalah amanah dari Allah. Setiap orang mendambakan lahirnya generasi yang unggul. Karena itu proses kehamilan sampai melahirkan menjadi suatu proses yang harus diperhatikan. Ada tiga hal yang harus diperhatikan oleh orangtua, yaitu memberi nama yang baik, mencarikan tempat pendidikan yang layak bermuatan moral agama, dan menikahkan apabila anak tersebut
\end{abstract}

* H. Moh. Rifai adalah Dosen Prodi PGSD FIP IKIP PGRI MADIUN 
telah menemukan jodohnya. Tiga hal tersebut melekat pada diri orangtua, ketika masuk usia peralihan dari masa balita ke masa pendidikan dasar, akan terjadi goncangan karena anak pada mausia tersebut sangat rentan dan mudah bereaksi serta agresif, sebab ketika masuk di sekolah awal anak mengganggap orangtuanya mencoba untuk memisahkan dirinya dan diserahkan ke orang lain yang tidak dikenalnya, walaupun itu gurunya. Hal ini menjadi penting bagaimana peralihan usia belajar kelas dasar tersebut bisa menjadi transfer keilmuan yang wajar dan bisa diterima oleh anak seusia tersebut. Sehingga bagi guru dan lembaga pendidikan dasar, harus mampu menyambut bola dengan beraneka model metode pendidikan agar peralihan kasih sayang dari orangtua ke pendidik tidak menjadikan beban mental bagi anak dan cara yang terbaik serta berkesan adalah menggunakan model pendekatan pola parenting (orangtua asuh) dengan begitu anak akan tidak merasa terputus kasih sayang dari orangtuanya karena tuntutan pendidikan yang harus dilewatinya.

Kata Kunci: Model Parenting, Optimalisasi Pendidikan Anak

\section{A. PENDAHULUAN}

Anak adalah anugerah terindah yang diberikan Tuhan, sebagai satu amanah yang harus dijaga tumbuh dan berkembangnya dengan baik. Kehadiran anak bagi orangtua, mampu membawa dan menambah keharmonisan hubungan dalam keluarga juga merupakan harapan besar dari setiap hal yang dilakukan orangtua demi terwujudnya putra-putri yang soleh maupun yang solihah, oleh karena itu orangtua senantiasa berusaha untuk mencarikan yang terbaik buat pendidikan serta masa depan anak-anaknya. Di era globalisasi saat ini jeritan kesedihan orangtua sering kita lihat, baik di media, sering menayangkan kejadiankejadian yang bersifat tindakan melawan hukum, kebrutalan, pelecehan seksual atau dan perbuatan-perbuatan yang tidak semestinya di lakukan oleh anak-anak di usia yang masih dini. Hal ini menjadikan sebuah evaluasi tersendiri bagi orangtua sebetulnya siapa yang salah dari kejadian tersebut, orangtua kah atau anak yang salah? Sementara orangtua berpandangan bahwa pendidikan anak harus bisa mengarah pada jenjang yang kedepannya membawa pada pekerjaan yang mapan dan tidak berfikir tentang pentingnya moral dan agama. Sementara yang lainya berpandangan bahwa pendidikan yang mempunyai nilai investasi moral serta agama yang baik adalah menjadi kebanggaan karena beranggapan bahwa anak yang dididik dengan moralitas yang baik dan agama yang cukup kedepanya akan bisa mandiri dan menjadi anak yang berbakti kepada orangtuanya.

Dengan lahirnya dua pandangan tersebut, maka kebanyakan orangtua mulai memilah-milah lembaga mana yang layak untuk dijadikan tempat pendidikan putra-putrinya, dan akibat dari itu orangtua mulai cenderung pada pendidikan yang mempunyai mulok (muatan lokal) yang mengadopsi keduaduanya. Maka orangtua cenderung mencari pendidikan yang bernuansa imtak dan iptek dengan harapan kelak putra-putrinya menjadi manusia yang taat pada negara, dan mempunyai pengetahuan yang dalam serta mampu bekerja dan menjadi manusia yang takwa kepada Tuhan Yang Maha Esa. Pendidikan dasar 
pada umumnya belum mengadopsi dua aspek moral dan pengetahuan karena model tersebut hanya ada dibeberapa lembaga yang dikelola oleh yayasan yang berbasis keagamaan. Selain itu juga orangtua mulai memilih-milih guru yang mengajar di lembaga tersebut, apakah guru itu dapat menjadi parenting bagi anakanak mereka? Karena hal ini dianggap menjadi penentu keberhasilan pendidikan di tingkat dasar pada anak-anaknya.

\section{B. PEMBAHASAN}

\section{Pengertian Pola Asuh}

Pola asuh adalah tata sikap atau perilaku yang digunakan oleh orangtua untuk mendidik atau merawat anaknya. Menurut Hurlock (2005:44), pola asuh orangtua adalah interaksi aturan norma tata nilai yang berlaku pada masyarakat dalam mendidik dan merawat anak-anaknya. Poerwadarminta menyatakan pola asuh orangtua adalah gambaran, tata cara atau perbuatan yang dilakukan orangtua (ibu / bapak / wali), dalam menjaga, mendidik serta merawat anaknya (Daryati, 2007: 14). Disamping lingkungan sosial yang dimiliki oleh seorang anak, pola asuh orangtua akan turut menentukan terbentuknya sikap dan watak anak dalam menjalani hidupnya. Jadi dapat disimpulkan bahwa cara bagaimana sikap orangtua untuk mendidik dan mengasuh anaknya, sehingga terbentuknya sikap dan watak anak dari pola asuh yang telah dipilih orangtua. Contohnya bila orangtua telah memilih pola asuh otoriter, maka sikap anak dan wataknya akan cenderung menjadi otoriter pula, begitu juga sebaliknya.

\section{Macam-macam Pola Asuh Orangtua}

Terdapat beberapa jenis pola asuh. Seorang ahli pola asuh terkemuka, Baumrind menyatakan terdapat bentuk utama gaya pengasuhan yaitu:

a. Pola Asuh Ototarian (Authotarian Parenting Style)

Pola asuh ini bersifat membatasi dan menghukum, mendesak anak untuk mengikuti kata orangtua mereka, harus hormat pada orangtua mereka, memiliki tingkat kekakuan (strictness) yang tinggi, dan memiliki intensitas komunikasi yang sedikit. Baumrind menyatakan bahwa anak yang dididik secara otoritarian ini memiliki sikap yang kurang kompenten secara sosial, keterampilan komunikasi yang buruk, dan takut akan perbandingan sosial. Dengan gaya otoritarian seperti ini anak dimungkinkan memberontak karena tidak terima atau bosan dengan pengekangan. Karena remaja ingin mencari tahu tanpa ingin dibatasi. Dengan pola asuh ini, probabilitas munculnya perilaku menyimpang pada remaja menjadi semakin besar.

\section{b. Pola Asuh Otoritatif (Authoritatve Parenting Style)}

Menurut Chadler pola asuh ini memiliki karakteristik berupa intensitas tinggi akan kasih sayng, keterlibatan orangtua, tingkat kepekaan orangtua terhadap anak, nalar, serta mendorong pada kemandirian. Orangtua yang menerapkan pola asuh seperti ini memiliki sifat yang sangat demokratis, memberikan kebebasan kepada anak tetapi tetap memberi batasan untuk mengarahkan anak menentukan keputusan yang tepat dalam hidupnya. Anak yang dididik dengan pola asuh ini memiliki tingkat kompetensi sosial yang tinggi, percaya diri, memiliki kemampuan berkomunkasi yang baik, akrab dengan teman sebaya mereka, dan mengetahui konsep harga diri yang tinggi. sehingga proses 
anak dalam menimbulkan perilaku tindakan antisocial cenderung bisa dibatasi. Karena walaupun anak dibebaskan, orangtua tetap terlibat dengan memberi batasan berupa peraturan yang tegas.

\section{c. Pola Asuh Mengabaikan (Negleckful Parrenting Style)}

Pola asuh ini bercirikan peran orangtua yang tidak terlibat dalam kehidupan anak karena cenderung lalai. Urusan anak dianggap oleh orangtua sebagai bukan urusan mereka atau orangtua menganggap urusan sang anak tidak lebih penting dari urusan mereka. Bumrind menyatakan anak yang diasuh dengan gaya seperti ini cenderung kurang cakap secara sosial, memiliki kemampuan pengendalian diri yang buruk, tidak memiliki kemandirian diri yang baik, dan tidak bermotivasi untuk berprestasi. Dalam konteks ini timbulnya perilaku penyimpangan oleh remaja, pola asuh seperti ini menghasilkan anak anak yang cenderung memiliki frekuensi tinggi dalam melakukan tindakan anti sosial. Karena mereka tidak biasa untuk diatur sehingga apa yang mereka mau lakukan, mereka akan lakukan tanpa mau dlarang oleh siapapun.

\section{d. Pola Asuh Memanjakan (Indulgent Parenting Style)}

Orangtua menjadi sangat terlibat dengan anak-anak mereka. Mereka menuruti semua kemauan anak mereka, dan sangat jarang membatasi perilaku anak mereka. Anak yang dihasilkan dengan pola asuh seperti ini, merupaka anakanak yang sulit untuk mengendalikan perilaku mereka sendiri, karena terbiasa untuk dimanja. Anak-anak seperti ini dapat seenaknya untuk melakukan tindakan perilaku menyimpang, karena terbiasa dengan sistem "apa saja dibolehkan". Sehingga kemungkinan timbul dan terulangnya perilaku menyimpang menjadi sangat besar.

Sedangkan menurut Balson, ada dua macam pola asuh yang selama ini digunakan oleh masyarakat yaitu:

a. Pola Asuh Koersif: Tertib tanpa Kebebasan

Pola asuh koersif hanya mengenal hukuman dan pujian dalam berinteraksi dengan anak. Pujian akan diberikan ketika anak melakukan sesuatu sesuai dengan keinginan orangtua. Sedangkan hukuman akan diberikan ketika anak tidak melakukan yang sesuai dengan keinginan orangtua. Akibat penerapan pola asuh koersif ini akan muncul empat tujuan anak berperilaku negatif yaitu: mencari perhatian, unjuk kekuasaan, pembalasan dan penarikan diri. ketika seorang anak dipaksa untuk melakukan perbuatan yang sesuai dengan keinginan orangtua dan dengan cara yang dikehendaki oleh orangtua maka anak akan kembali menuntut orangtua nya untuk memberikan perhatan atau pujian kepadanya.

Sebaliknya jika anak tidak dapat memenuhi tuntunan orangtua nya maka ia akan merasa hidupnya tidak berharga maka dia akan menarik dirinya dari kehidupan. Pada saat orangtua menghukum anak karena anak tidak mematuhi keinginannya maka anak akan belajar untuk mencari kekuasaan karena dia merasakan bahwa karena dia tidak memiliki kekuasaanlah dia jadi terhina, jika dia tidak mendapatkan kekuasaan tersebut maka dia akan menanti nanti saat yang tepat baginya untuk membalas semua perilaku tak enak yang dia terima selama ini. Orangtua yang koersif beranggapan bahwa mereka dapat merubah perilaku anak yang tidak sesuai dengan nilai yang mereka anut dengan cara mencongkel 
perilaku itu lalu menggantikan dengan perilaku yang mereka kehendaki tanpa memperdulikan perasaan anaknya.

b. Pola Asuh Diagonis: Tertib dengan Kebebasan

Pola asuh ini datang sebagai jawaban atas ketiadaannya pola asuh yang sesuai dengan fitrah penciptaan manusia. Berpijak kepada dorongan dan konsekuensi dalam membangun dan memelihara fitrah anak. Orangtua menyadari bahwa anak adalah amanah Allah pada mereka, dia merupakan makhluk yang aktif dan dinamis. Aktivitas mereka bertujuan agar mereka dapat diakui keberadaanya, diterima kontribusinya, dicintai dan dimiliki oleh keluarganya. Dalam memperbaiki kesalahan anak, orangtua menyadari bahwa kesalahan itu muncul karena mereka belum terampil dalam melakukan kebaikan, sehingga mereka akan mencoba untuk membangun ketramplan tersebut dengan berpijak kepada kelebihan yang anak miliki, lalu mencoba untuk memperkecil hambatan yang membuat anak berkecil hati untuk memulai kegiatan yang akan menghantarkan mereka kepada kebaikan tersebut. Kemudian orangtua juga akan berusaha menerima keadaan anak apa adanya tanpa membanding bandingkan mereka dengan orang lain bahkan saudara kandung mereka sendiri, atau teman bermainya.

Orangtua akan membiasakan diri berdialog dengan anak dalam menemani tumbuh kembang anak mereka. Setiap kali ada persoalan anak dilatih untuk mencari akar persoalan, lalu diarahkan untuk ikut menyelesaikan secara bersama. Dengan demikian anak akan merasakan bahwa hidupnya penuh arti sehingga dengan lapang dada dia akan merujuk kepada orangtua nya jika dia mempunyai persoalan dalm kehidupannya. Hal ini berarti pula orangtua dapat ikut bersama anak untuk mengantisipasi bahaya yang mengintai kehidupan anak anak setiap saat. Selain itu orangtua yang dialogis akan berusaha mengajak anak agar terbiasa menerima konsekuensi secara logis dalam setiap tindakanya. Sehingga anak akan menghindari keburukan karena dia sendiri merasakan akibat perbuatan buruk itu, bukan karena desakan dari orangtuanya.

\section{Tipe Pola Asuh (Parenting Style) Otoritatif}

a. Pengertian Pola Asuh Otoriter

Pola asuh otoriter adalah pola asuh dimana orangtua mencoba mengontrol dan menuntut ketaatan, mereka mencoba untuk membuat anak mengikut standar tingkah laku yang ditetapkan dan bertindak sewenang-wenang, menghukum mereka yang melanggar aturan, mereka lebih objektif dan kurang hangat dibandingkan orangtua lainya, anak menjadi tidak puas, suka menyendiri, curiga, dan tidak percaya diri. Pola asuh otoriter dapat dimaknai sebagai pola asuh yang pemegang perananya adalah orangtua, semua kekuasaan ada pada orangtua, semua keaktifan anak ditentukan olehnya (Aprimaryati, 2004).

Anak sama sekali tidak mempunyai hak untuk mengemukakan pendapat, anak dianggap anak kecil terus-menerus, anak tidak pernah dapat perhatian yang layak sehingga semua keinginan dan cita-citanya tidak mendapat perhatian. Menurut Stewart dan Koch, orangtua yang menerapkan pola asuh otoriter mempunyai sikap: kaku, tegas, suka menghukum, kurang adanya kasih sayang serta simpatik. Orangtua memaksa anak untuk patuh pada nilai nilai mereka, dan 
mencoba membentuk tingkah laku sesuai dengan tingkah lakunya serta cenderung mengekang keinginan anak.

\section{b. Ciri-ciri Orangtua yang Otoriter}

Secara umum perlakuan orangtua yang otoriter terhadap anak ditandai cirri-ciri: (1) orangtua yang dikatakan otoriter penuh berwibawa tetapi kewibawaan yang dimiliki hanya kewibawaan lahiriah; (2) perlakuan orangtua yang otoriter mengakibatkan hubungan orangtua dan anak tidak akrab, riter terhadap anaknya; (3) segala yang menjadi kebutuhan anak ada ditangan orangtua; dan (4) segala bentuk yang harus ditempuh atau dilakukan melalui perintah dan larangan tanpa disertai pengertian, jika ditaati mendapat hadiah dan jika tidak ditaati mendapat hukuman. Jika ciri-ciri tersebut dimiliki orangtua, maka orangtua tersebut memiliki perlakuan yang otoriter.

\section{c. Perilaku Orangtua yang Otoriter}

Adapun perilaku orangtua otoriter menurut Idris adalah (1) anak harus mematuhi peraturan-peraturan orangtua dan tidak boleh membantah; (2) orangtua cenderung mencari kesalahan-kesalahan pada pihak anak, dan kemudian menghukumnya; (3) jika terdapat perbedaan pendapat antara anak dan orangtua maka anak akan dianggap sebagai orang yang suka melawan dan membangkang; (4) orangtua cenderung memberikan perintah dan larangan terhadap anak; (5) orangtua cenderung memaksakan disiplin; dan (6) orangtua cenderung menentukan segala sesuatu untuk anak, dan haknya sebagai pelaksana (orangtua sangat berkuasa). Dampak pola pengasuhan orangtua yang otoriter, permisif, dan otoritarif terhadap kebiasaan (karakter) anak seperti pada Tabel 1.

Tabel 1 Dampak Pola Pengasuhan Orangtua terhadap Kebiasaan (Karakter) Anak

\begin{tabular}{|c|c|c|}
\hline Tipe & Perlakuan Orangtua & Karakteristik Anak \\
\hline Otoriter & $\begin{array}{l}\text { Kontrol yang ketat dan penilaian yang } \\
\text { kritis terhadap perilaku anak, sedikit } \\
\text { dialog (memberi dan menerima) secara } \\
\text { verbal, kurang hangat dan kurang } \\
\text { terjalin secara emosional. }\end{array}$ & $\begin{array}{l}\text { Menarik diri dari pergaulan serta } \\
\text { tidak puas dan tidak percaya } \\
\text { terhadap orang lain. }\end{array}$ \\
\hline Permisif & $\begin{array}{l}\text { Tidak mengontrol: tidak menuntut, } \\
\text { sedikit menerapkan hukuman atau } \\
\text { kekuasaan, penggunaan nalar, hangat } \\
\text { dan menerima. }\end{array}$ & $\begin{array}{l}\text { Kurang dalam kendali diri dan } \\
\text { kecenderungan untuk berekplorasi. }\end{array}$ \\
\hline Otoritatif & $\begin{array}{l}\text { Mengontrol, menuntut, hangat, } \\
\text { represif, rasional, berdialog (member } \\
\text { dan menerima) secara verbal, } \\
\text { menghargai disiplin, kepercayaan diri, } \\
\text { dan keunikan. }\end{array}$ & $\begin{array}{l}\text { Mandiri, bertanggung jawab secara } \\
\text { sosial, memliki kendali diri, bersifat } \\
\text { eksploratif, dan percaya diri. }\end{array}$ \\
\hline
\end{tabular}

\section{Guru-Anak Didik sebagai Dwi Tunggal}

Guru adalah unsur manusiawi dalam pendidikan. Guru adalah figur manusia sumber yang menempati posisi dan memegang peranan penting dalam pendidikan. Ketika semua orang memersoalkan masalah dunia pendidikan, figur guru mesti terlibat dalam agenda pembicaraan, terutama yang menyangkut persoalan pendidikan formal di sekolah. Hal itu tidak dapat disangkal, karena 
lembaga pendidikan formal adalah dunia pendidikan kehidupan guru. Sebagian besar waktu guru ada di sekolah, sisanya di rumah dan di masyarakat. Di sekolah, guru hadir untuk mengabdikan diri kepada umat manusia dalam hal ini anak didik. Guru dengan buku dan ilmu pengetahuan, datang ke sekolah di waktu pagi hingga petang, sampai waktu mengajar dia hadir di kelas untuk bersama-sama belajar dengan sejumlah anak didik yang sudah menantinya untuk diberikan pelajaran. Anak didik ketika itu haus akan ilmu pengetahuan dan siap untuk menerimanya dari guru. Ketika itu guru sangat berarti sekali bagi anak didik. Kehadiran guru di kelas merupakan kebahagiaan bagi mereka. Apalagi bila figur guru disenangi oleh mereka sebagai orangtua angkat mereka / parenting.

Guru dan anak didik adalah dua sosok manusia yang tidak dapat dipisahkan dari dunia pendidikan. Boleh jadi, dimana guru disitu ada anak didik yang ingin belajar dari guru. Sebaliknya, dimana ada anak didik disana ada guru yang ingin memberikan pembinaan dan bimbingan kepada anak didik. Guru dengan ikhlas memberikan apa yang diinginkan oleh anak didiknya. Tidak ada sedikit pun di benak guru terlintas pikiran negatif untuk tidak mendidik anak didiknya, meskipun barangkali sejuta permasalahan sedang merongrong kehidupan seorang guru. Pada hakikatnya guru dan anak didik itu bersatu. Mereka satu dalam jiwa, terpisah dalam raga. Raga mereka boleh terpisah, tetapi jiwa mereka tetap satu sebagai "dwitunggal" yang kokoh bersatu. Posisi mereka boleh berbeda, tetapi tetap seiring setujuan, kesatuan jiwa guru dan anak didik tidak dapat terpisahkan oleh dimensi ruang, jarak, dan waktu. Tidak pula dapat di ceraiberaikan oleh lautan, daratan, dan udara. Guru tetap guru dan anak didik tetap anak didik. Tidak ada istilah "bekas guru" dan bekas "anak didik" meskipun suatu waktu guru telah pensiun dari pengabdianya di sekolah atau anak didiknya telah menamatkan sekolah di lembaga tempat guru tersebut mengabdikan diri.

Menjadi guru berdasarkan tuntutan pekerjaan adalah suatu perbuatan yang mudah, tetapi menjadi berdasarkan panggilan jiwa atau tuntunan hati nurani adalah tidak mudah, karena kepadanya lebih banyak dituntut suatu pengabdian kepada anak didik daripada tuntutan pekerjaan dan material oriented. Guru yang mendasarkan panggilan jiwa merasakan jiwanya lebih dekat dengan anak didiknya. Ketiadaan anak didiknya di kelas menjadi pemikiranya, kenapa anak didiknya tidak hadir di kelas, apa yang menyebabkanya, dan berbagai pertanyaan yang mungkin guru ajukan ketika itu.

Uraian di atas adalah gambaran figur guru dengan segala kemuliaanya, yang mengabdikan diri berdasarkan panggilan jiwa, bukan karena pekerjaan sampingan. Oleh karena figur guru yang demikian diharapkan dari siapa pun yang ingin menerjunkan dirinya ke dalam dunia pendidikan di sekolah. Figur guru yang mulia adalah sosok guru yang rela hati mengabdikan waktunya demi kepentingan, demi membimbing, mendengarkan keluhan, menasihati, dan membantu kesulitan dalam segala hal yang bisa menghambat aktifitas belajar anak didik, merasakan kedukaannya sama dengan mereka, bersama-sama dengannya di waktu senggangnya, berbicara dan bersenda gurau di sekolah, diluar jam kegiatan interaksi edukatif di kelas, bukan hanya duduk di kantor dengan dewan guru, dan membuat jarak dengan anak didik. Akhirnya guru dan anak didik adalah sebagai dwitunggal. Kemuliaan guru tercermin pada pengabdianya kepada anak didik dalam interaksi edukatif di sekolah dan di luar sekolah. 


\section{Guru mitra anak didik dalam kebaikan}

Di sekolah, guru adalalah orangtua kedua bagi anak didik. Sebagai orangtua, guru harus menganggap dirinya sebagai bagian darinya, bukan menganggapnya sebagai peserta didik. Istilah peserta didik lebih sesuai diberikan kepada mereka yang mengikuti kegiatan-kegiatan latihan dan pendidikan yang waktunya relatif singkat, yakni sebulan atau tiga bulan bahkan seminggu. Misalnya seperti kursus-kursus kilat. Penyebutan istilah anak didik lebih sesuai digunakan sebagai mitra guru disekolah. Guru adalah orangtua. Anak didik adalah anak dan anak adalah dua sosok insani yang didikat oleh tali jiwa. Belaian kasih sayang adalah naluri jiwa orangtua yang sangat diharapkan oleh anak, sama halnya belaian kasih dan sayang seorang guru kepada anak didiknya.

\section{Pendekatan yang diharapkan dari guru}

Dalam interaksi edukatif yang berlangsung telah terjadi interaksi yang bertujuan pola parenting. Guru sebagai orangtua angkat dan anak didik sebagai anak angkatnya. Interaksi tersebut bertujuan menciptakan lingkungan yang bernilai edukatif demi kepentingan anak didik dalam belajar. Guru ingin memberikan layanan yang terbaik kepada anak didik, dengan menyediakan lingkungan yang menyenangkan dan menggairahkan. Guru berusaha menjadi pembimbing yang baik dengan peranan yang arif dan bijkasana, sehingga tercipta hubungan dua arah yang harmonis antara guru dan anak didik. Ketika interaksi edukatif itu berproses, guru harus dengan ikhlas dalam bersikap dan berbuat dan mau memahami anak didiknya dengan segala konsekuensinya. Semua gejala yang menjadi penghambat jalanya interaksi proses edukatif, baik yang berpangkal dari perilaku anak didik maupun yang bersumber dari luar diri anak didik, harus dihilangkan, dan bukan membiarkanya. Karena keberhasilan interaksi edukatif lebih banyak ditentukan oleh guru dalam mengelola kelas.

\section{PENUTUP}

Pendidikan adalah merupakan suatu bidang pengabdian dan kemanusiaan. Guru harus berupaya untuk menunjukkan karyanya sebagai guru dengan mengadopsi dasar-dasar, yaitu: (1) guru berbakti membimbing anak didik seutuhnya untuk membentuk manusia pembangunan yang berjiwa Pancasila; (2) guru memiliki kejujuran profesional dalam menetapkan kurikulum sesuai dengan kebutuhan anak didik masing-masing; (3) guru mengandalkan komunikasi terutama dalam memperoleh informasi tentang anak didik tetapi menghindarkan diri dari segala bentuk penyalahgunaan; (4) guru menciptakan suasana kehidupan sekolah dan memelihara hubungan dengan orangtua murid sebaik-baiknya bagi kepentingan anak didik; (5) guru memelihara hubungan baik dengan masyarakat di sekitar sekolahnya maupun masyarakat yang lebih baik untuk kepentingan pendidikan; (6) guru secara sendiri-sendiri dan atau bersama-sama berusaha mengembangkan dan meningkatkan mata pelajarannya; (7) guru menciptakan dan memelihara hubungan antara sesama guru baik berdasarkan lingkungan kerja maupun didalam hubungan keseluruhan; dan (8) guru melakasanakan segala ketentuan yang merupakan kebijaksanaan pemerintah dalam bidang pendidikan. 


\section{DAFTAR PUSTAKA}

Azra, A. 1989. Perspektif Islam di Asia Tenggara. Jakarta: Yayasan Obor Indonesia.

Cholidjah, H. 1995. Kajian Perbandingan Pendidikan. Surabaya: Al-Ikhlas.

Departemen Pendidikan dan Kebudayaan. 1980. Laporan Komisi Pembaharuan Pendidikan Nasional. Jakarta: Depdikbud.

Faisal, S. 2007. Partisipasi Masyarakat terhadap Sekolah: Ringkasan Hasil Ujian. Malang: UM Press.

Latif, A. 2007. Pendidikan Berbasis Nilai Kemasyarakat. Bandung: Refika Aditama.

Mahfud, C. 2009. Pendidikan Miltikultural. Yogyakarta: Pustaka Pelajar.

Nurcahyo, A., dan Hartono, Y. 2010. Konsep Dasar dan Pengembangan IPS-SD. Madiun: Swastika Press.

Lauer, R. H. 2001. Perspektif tentang Perubahan Sosial. Jakarta: Rineka Cipta.

Rudito, B., dan Melia, F. 2008. Social Mapping, Metode Pemetaan Sosial, Teknik Memahami suatu Masyarakat atau Komuniti. Bandung: Rekayasa Sains.

Spredley, J. 1980. Participant Observation. New York: Holt Renehart and Winston.

Syukur, T. 2008. Teknologi Pendidikan. Semarang: Rasail. 